\title{
A model of customer loyalty in the retail banking market
}

\author{
Hadi Hajiyan $^{a^{*}}$, Ali Akbar Aminbeidokhtib ${ }^{\mathrm{b}}$ and Hadi Hemmatian ${ }^{\mathrm{a}}$
}

${ }^{a}$ Department of Management, Islamic Azad University, Semnan Branch, Semnan, Iran ${ }^{b}$ Department of Management, University of Semnan, Semnan, Iran

\section{CH R O I C LE A B S T RACT}

Article history:

Received December 5, 2015

Received in revised format

February 162016

Accepted August 142016

Available online

August 152016

Keywords:

Customer loyalty

Banking industry

Quality of services

\section{Introduction}

During the past two decades, there has been growing trend in Iranian banking industry due to change in banking regulations. Private sector has grown rapidly and there have been several new banks on the market, which has created very competitive market. Therefore, customer loyalty is the key factor for running a successful banking business and customer relationship management (CRM) (Ebrahimi et al., 2016) appears to be important for having successful banking operations. In fact, customer satisfaction is one of the primary components of modern marketing. Most businesses may only survive as long as they are to meet the customers' requirements. Thus, it is extremely essential in today's intensively competitive environment to be in regular contact with the customers. Banking industry is one of the sectors in which competition is experienced intensively and they are the finance institutions that meet the economic requirements of the individuals and businesses and that execute economic activities by collecting bank deposits, granting credits, generating capital, etc. During the past few years, there have been important developments to understand modern banking. With the transition to automation,

* Corresponding author. Tel: +989128310675

E-mail address: hadihajiyan61@yahoo.com (H. Hajiyan)

(C) 2017 Growing Science Ltd. All rights reserved.

doi: $10.5267 /$ j.ac. 2016.8 .002 
customer satisfaction and management of customer relationships have been among the subjects of studies in the banking sector. There are literally many studies on different types of CRM. Sivaraks et al. (2011), for instance, performed an investigation on the outcomes of electronic CRM (e-CRM) system implementation in the Thai banking industry from customers' perspectives. Since many e-CRM implementations are not seen directly by customers, the authors performed interviews with some experts in the Thai banking industry to develop a new framework called 'customer-based service attributes' to compute e-CRM outcomes from customers' perspectives. They reported that e-CRM implementation had a statistically significant positive relationship with customer-based service attributes and with the quality and outcome of customer-bank relationships.

Wal-Mart is considered a benchmark of a firm that uses a blend of high-tech solutions and high-touch employees-like flesh-and blood greeters-to increase customer loyalty. Wal-Mart allows technology work behind the scenes by using one of the biggest CRM data warehouse in the world, which helps track what the customers purchase precisely. Therefore, WalMart stocks more of the most popular goods, and clusters items that customers more likely to buy at the same time. But Wal-Mart does not implement the technology to keep individual customers' profile and leaves that job to its local staff, who are more familiar with their regular customers and understand their requirements (Rigby et al., 2003). In other words, CRM software may increase customer loyalty in different ways such as tracking customer defection and retention levels and telling us how satisfied customers are but in the end, technology is not obviously the answer. In fact, the prime driver of customer loyalty is the loyalty of the firm's employees (Rigby et al., 2003).

Zineldin (2006) provided a better insight of triangle relationship between quality, CRM and customer loyalty (CL) which might lead to companies' competitiveness (CC). They designed a model (5Qs) to measure satisfaction and loyalty based on two conditions of the customer database and CRM strategy and that management control systems have the capacity to produce needed data for the analysis. They reported that changing in quality over time within different segments or associated with specific products or categories of products/services could be implemented as an indicator the level of loyalty. Bhat and Darzi (2016) developed an integrated framework to explain the effect of CRM dimensions (complaint resolution, customer knowledge, customer empowerment and customer orientation) on customer loyalty and competitive advantage of a bank. They also explored the mediating role of customer loyalty in the relationship between CRM and competitive advantage in retail banking. They reported that the four CRM dimensions had a positive impact on customer loyalty and competitive advantage of the bank and customer knowledge was the most influential of all the dimensions among CRM components.

According to Abesy and Torkan (2016), technology has led most firms to offer their products and services with higher quality and reduced prices to their loyal customers. Therefore, with the sole use of the advanced technology or cheaper price in comparison to the competitors the competitive advantage may not necessarily be reached and a customer is the only reliable competitive advantage for the firms. Osayawe Ehigie (2006) performed a survey to explore customers' expectations from bank services on the basis of which measurement scales were developed among employees of Nigerian bank including operators of savings, current, and electronic bank accounts. He reported that perception of service quality and satisfaction were substantial predictors of customer loyalty, with customer satisfaction contributing more. Caruana (2002) reported that customer satisfaction play a mediating role in the impact of service quality on service loyalty. Newman (2001) presented a case study of a pioneering nationwide implementation of SERVQUAL (Parasuraman et al., 1988) by a major UK high street bank over the period 1993-1997 at an annual cost of one million pounds. They reported that customer loyalty could contribute significantly on the success of banking operations. 


\section{The proposed study}

The primary objective of this paper is to investigate the relationship between CRM and customer loyalty in one of the oldest Iranian banks named Bank Melli Iran. The study designs a questionnaire in Likert scale with 30 questions and distributes it among some customers, randomly who do their banking business activities with Bank Melli Iran in city of Semnan, Iran. Since the population of this survey is unlimited we use the following to measure the sample size,

$$
N=Z_{\alpha / 2}^{2} \frac{p \times q}{e^{2}},
$$

where $N$ is the sample size, $p=1-q$ is the probability, $z_{\alpha / 2}$ denotes CDF of normal distribution and finally $\varepsilon$ represents the error term. For the proposed study of this paper we assume $p=0.5, z_{\alpha / 2}=1.96$ and $e=0.05$, the number of sample size is calculated as $N=59$. We distribute 65 questionnaires to make sure we reach the desirable accuracy. Fig. 1 shows personal characteristics of the participants.

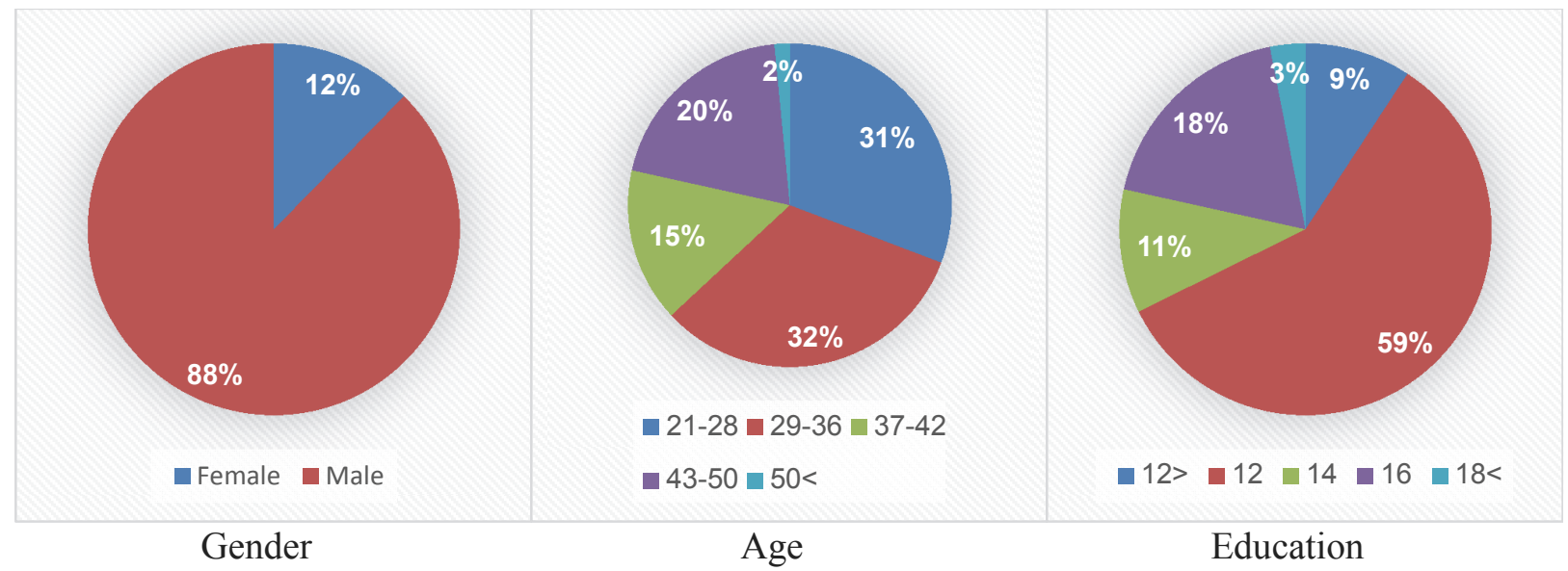

Fig. 1. Personal characteristics of the participants

As we can see from the results of Fig. 1, 88\% of the respondents in our survey were male, $77 \%$ had no university education and $80 \%$ of them aged at least 28 years old. Moreover, Kolmogorov-Smirnov test has confirmed that the questionnaire data were normally distributed. Our study examine two hypotheses where the first hypothesis tests whether people with different personal characteristics had various expectations from their banks in terms of quality of services and the second hypothesis investigates whether there is any relationship between CRM and quality of services.

\section{The results}

The first part of the survey examines the relationship between customer's personal characteristics and quality of services.

\subsection{The relationship between personal characteristics and quality of services as well as loyalty}

\subsubsection{The impact of gender on quality of services and loyalty}

In this study, we use Levene's test and t-test to examine the effects of gender on quality of services and customer loyalty. Table 1 shows the results of the survey. 
Table 1

The summary of Levene's test and t-test on the effects of gender on quality of services and loyalty

\begin{tabular}{llccccc}
\hline & & \multicolumn{3}{c}{ Levene's test } & \multicolumn{2}{c}{ t-test } \\
\cline { 2 - 6 } & & $\mathrm{F}$ & Sig. & $\mathrm{t}$ & $\mathrm{df}$ & Sig. \\
\hline Quality of services & $\mathrm{H}_{0}: \sigma_{1}{ }^{2}=\sigma_{2}{ }^{2}$ & 1.452 & 0.233 & 0.082 & 63 & 0.935 \\
& $\mathrm{H}_{1}: \sigma_{1}{ }^{2} \neq \sigma_{2}{ }^{2}$ & & & 0.064 & 8.081 & 0.950 \\
\hline Customer loyalty & $\mathrm{H}_{0}: \sigma_{1}{ }^{2}=\sigma_{2}{ }^{2}$ & 0.025 & 0.875 & -1.205 & 63 & 0.233 \\
& $\mathrm{H}_{1}: \sigma_{1}{ }^{2} \neq \sigma_{2}{ }^{2}$ & & & & 9.132 & 0.255 \\
\hline
\end{tabular}

Based on the results of Table 1, gender shows no meaningful effect on quality of services and loyalty.

\subsubsection{The impact of age on quality of services and loyalty}

The proposed study of this paper implements ANOVA test to measure the effect of age on participants' personal characteristics on quality of services as well as customer loyalty and Table 2 demonstrates the results of the survey.

Table 2

The summary of ANOVA test on the effects of age on quality of services and loyalty

\begin{tabular}{llccccc}
\hline & & Sum of Squares & df & Mean Square & F & Sig. \\
\hline Quality of services & Between group & 233.235 & 4 & 58.309 & 0.539 & 0.708 \\
& Within group & 6489.227 & 60 & 108.154 & & \\
\cline { 2 - 7 } & Total & 6722.462 & 64 & & & 0.210 \\
\hline Customer loyalty & Between group & 490.010 & 4 & 122.502 & 1.514 & \\
& Within group & 4856.236 & 60 & 80.937 & & \\
\cline { 2 - 7 } & Total & 5346.246 & 64 & & & \\
\hline
\end{tabular}

As we can see from the results of Table 2, age maintains no meaningful effect on quality of services and loyalty.

\subsubsection{The impacts of education on quality of services and loyalty}

Again, the survey uses ANOVA to examine the effect of education on quality of services and customer loyalty and Table 3 shows the results of the survey.

Table 3

The results of ANOVA test on the effects of educational background on quality of services and loyalty

\begin{tabular}{|c|c|c|c|c|c|c|}
\hline \multirow{4}{*}{ Quality of services } & & Sum of Squares & $\mathrm{df}$ & Mean Square & $\mathrm{F}$ & Sig. \\
\hline & Between group & 758.150 & 4 & 189.538 & 1.907 & 0.121 \\
\hline & Within group & 5964.311 & 60 & 99.405 & & \\
\hline & Total & 6722.462 & 64 & & & \\
\hline \multirow{3}{*}{ Customer loyalty } & Between group & 843.994 & 4 & 210.999 & 2.812 & 0.033 \\
\hline & Within group & 4502.252 & 60 & 75.038 & & \\
\hline & Total & 5346.246 & 64 & & & \\
\hline
\end{tabular}

According to the results of Table 3, customer's educational background has no meaningful effect on quality of services. However, it has some impact on customer loyalty when the level of significance is $5 \%$.

\subsection{Main hypotheses}

In this survey, we investigate the impacts of CRM on quality of services and customer loyalty,

1. There is a meaningful relationship between CRM and quality of services.

2. There is a meaningful relationship between CRM and customer loyalty. 


\subsubsection{First hypothesis: The effect of CRM on quality of services}

The first main hypothesis of the survey tests the relationship between CRM and quality of services. Table 4 presents the results of one-way test.

\section{Table 4}

The results of one-way test on relationship between CRM and quality of services.

\begin{tabular}{lllcccc}
\hline & $\mathrm{t}$-value & $\mathrm{df}$ & Sig. & Mean difference & $95 \%$ confidence interval \\
\hline Quality of services & 10.105 & 64 & 0.000 & 85.641 & 0.6871 & 1.0257 \\
\hline
\end{tabular}

Based on the results of Table 4, CRM has shown a meaningful effect on quality of services $(\alpha=5 \%)$. Therefore, the first hypothesis of the survey has been confirmed.

\subsubsection{Second hypothesis: The relationship between CRM and customer loyalty}

The second hypothesis of the survey examines the relationship between CRM and customer loyalty. Table 5 presents the results of one-way test.

\section{Table 5}

The results of one-way test on relationship between CRM and customer loyalty

\begin{tabular}{lcccccc}
\hline & t-value & df & Sig. & Mean difference & $95 \%$ confidence interval \\
\hline Quality of services & 11.915 & 64 & 0.000 & 0.90051 & 0.7495 & 1.0515 \\
\hline
\end{tabular}

Based on the results of Table 5, there is a meaningful relationship between CRM and customer loyalty $(\alpha=1 \%)$. Therefore, the second hypothesis of the survey has been confirmed.

\section{Conclusion}

We have presented a survey to examine the relationship between customer's personal characteristics and service quality expectations. Using an empirical investigation, the study has determined that people with different age, gender and educational background maintained similar expectations from their banks. The study has also confirmed that there was a positive and meaningful relationship between CRM and customer loyalty. Our more in-depth survey has indicated that e-business facilities contributed significantly on customer loyalty and this consistent with findings reported by Lee-Kelley et al. (2003) and Liu et al. (2012). These days, many businesses such as banks, insurance firms, and other service providers have understood the relative importance of CRM and its potential to acquire new customers, retaining existing ones and maximize their lifetime value through providing need based services in the changing economic scenario (Kishor \& Nagamani, 2015). The results of this survey have emphasized that banking industry could be more successful only by providing comprehensive CRM and dedicated employees who serve their customers well.

\section{Acknowledgement}

The authors would like to thank the anonymous referees for constructive comments on earlier version of this paper.

\section{References}

Abesy, S., \& Torkan, V. (2016). Planning customer relationship management (CRM) strategies in the mining and industry bank. Mediterranean Journal of Social Sciences, 7(3 S3), 298.

Bhat, S. A., \& Darzi, M. A. (2016). Customer relationship management: An approach to competitive advantage in the banking sector by exploring the mediational role of loyalty. International Journal of Bank Marketing, 34(3), 388-410.

Caruana, A. (2002). Service loyalty: The effects of service quality and the mediating role of customer satisfaction. European journal of marketing,36(7/8), 811-828. 
Ebrahimi, E., Fathi, M. R., \& Irani, H. R. (2016). A new hybrid method based on fuzzy Shannon's Entropy and fuzzy COPRAS for CRM performance evaluation (Case: Mellat Bank). Iranian Journal of Management Studies,9(2), 333.

Kishor, N. R., \& Nagamani, K. (2015). Customer relationship management in Indian Banking Sector. ACADEMICIA: An International Multidisciplinary Research Journal, 5(7), 74-82.

Lee-Kelley, L., Gilbert, D., \& Mannicom, R. (2003). How e-CRM can enhance customer loyalty. Marketing Intelligence \& Planning, 21(4), 239-248.

Liu, C. C., Tseng, H. C., Chuang, L. M., \& Huang, C. M. (2012). A study of the impact of the E-CRM perspective on customer satisfaction and customer loyalty-exemplified by bank Sinopac. Journal of Economics and Behavioral Studies, 4(8), 467.

Newman, K. (2001). Interrogating SERVQUAL: a critical assessment of service quality measurement in a high street retail bank. International Journal of Bank Marketing, 19(3), 126-139.

Osayawe Ehigie, B. (2006). Correlates of customer loyalty to their bank: a case study in Nigeria. International Journal of Bank Marketing, 24(7), 494-508.

Parasuraman, A., Zeithaml, V. A., \& Berry, L. L. (1988). Servqual. Journal of retailing, 64(1), 12-40.

Rigby, D. K., Reichheld, F., \& Dawson, C. (2003). Winning customer loyalty is the key to a winning CRM strategy. Ivey business journal, 67(4), 1.

Sivaraks, P., Krairit, D., \& Tang, J. C. (2011). Effects of e-CRM on customer-bank relationship quality and outcomes: The case of Thailand.The Journal of High Technology Management Research, 22(2), 141-157.

Zineldin, M. (2006). The royalty of loyalty: CRM, quality and retention.Journal of Consumer Marketing, 23(7), 430-437. 